\title{
SERPIND1 wt Allele
}

National Cancer Institute

\section{Source}

National Cancer Institute. SERPIND1 wt Allele. NCI Thesaurus. Code C113636.

Human SERPIND1 wild-type allele is located in the vicinity of 22q11.21 and is approximately $14 \mathrm{~kb}$ in length. This allele, which encodes heparin cofactor 2 protein, is involved in heparin-dependent inhibition of thrombin. Mutation of the gene is associated with thrombophilia due to heparin cofactor 2 deficiency. 